\title{
Arable weed seeds as indicators of regional cereal provenance: a case study from Iron Age and Roman central- southern Britain
}

Article

Accepted Version

Lodwick, L. A. (2018) Arable weed seeds as indicators of regional cereal provenance: a case study from Iron Age and Roman central-southern Britain. Vegetation History and Archaeobotany, 27 (6). pp. 801-815. ISSN 0939-6314 doi: https://doi.org/10.1007/s00334-018-0674-y Available at https://centaur.reading.ac.uk/76820/

It is advisable to refer to the publisher's version if you intend to cite from the work. See Guidance on citing.

To link to this article DOI: http://dx.doi.org/10.1007/s00334-018-0674-y

Publisher: Springer

All outputs in CentAUR are protected by Intellectual Property Rights law, including copyright law. Copyright and IPR is retained by the creators or other copyright holders. Terms and conditions for use of this material are defined in the End User Agreement. 


\section{CentAUR}

Central Archive at the University of Reading

Reading's research outputs online 
Title: Arable weed seeds as indicators of regional cereal provenance: a case study from Iron Age and Roman central-southern Britain

Journal: Vegetation History and Archaeobotany

Lisa A. Lodwick

University of Oxford

Email: Lisa.lodwick@all-souls.ox.ac.uk

Orcid ID: orcid.org/0000-0002-0473-2589

\begin{abstract}
The ability to provenance crop remains from archaeological sites remains an outstanding research question in archaeology. Archaeobotanists have previously identified the movement of cereals on the basis of regional variations in the presence of cereal grain, chaff and weed seeds (the consumer-producer debate), and the use of weed seeds indicative of certain geological areas, principally at Danebury hillfort. Whilst the former approach has been heavily criticised over the last decade, the qualitative methods of the latter have not been evaluated.

The first interregional trade in cereals in Britain is currently dated to the Iron Age hillfort societies of the mid first millennium BC. Several centuries later, the development of urban settlements in the Late Iron Age and Roman period contained residents reliant on food produced elsewhere. Using the case study of central-southern Britain, centred on the oppidum and civitas capital of Silchester, this paper presents the first regional quantitative analysis of arable weed seeds in order to identify cereal origin. Analysis of the weed seeds present alongside the fine-sieving by-products of the glume wheat Triticum spelta (spelt wheat) shows that the weed floras of samples from diverse geological areas can be separated on the basis of the geological preferences of individual taxa. A preliminary finding is that rather than being supplied with cereals from the wider landscape of the Hampshire Downs, crops were produced within close proximity of Late Iron Age Silchester. The method presented here requires further high quality samples to evaluate this, and other instances of cereal movement in the past.
\end{abstract}

\title{
Keywords
}

Iron Age - Roman - oppida - exchange - cereals - archaeophytes

\section{Acknowledgments}

This research was undertaken during an AHRC funded PhD (grant number AH/I01215X/1) at the University of Oxford. I am grateful to Prof Mark Robinson and Dr Mike Charles for advice with this research, and to Dr Chris Stevens for providing data from Abingdon Vineyard. Prof Mike Fulford provided comments on the text. I am grateful for the constructive feedback from two anonymous reviewers. 


\section{Introduction}

The movement of agricultural resources is a key aspect in the consideration of the socioeconomic organisation of past societies (Erdkamp 2008; Hill 2011; Moore 2007). The emergence of hillforts, oppida and Roman towns during the first millenniums $B C$ and $A D$, has long been associated with the long-distance movement of cereal crops (Jones 1981; Van der Veen and O'Connor 1998). However, archaeological food provenancing studies have primarily focussed on animal resources, such as the sourcing of pigs for Iron Age feasting (Madgwick and Mulville 2015), the movement of Iron Age horse and cattle (Bendrey et al. 2009; Minniti et al. 2014), and the supply of animals to the Roman fortress at Caerleon (Madgwick et al. 2017). Inferences on the origin of cereals have so far been drawn from qualitative assessments of charred arable weeds identified alongside charred cereal grains and chaff (Helbaek 1964; Jones M 1984). In light of recent developments in the application of stable isotope analysis of charred cereal grains in order to provenance cereals (Bogaard et al. 2014; Lightfoot and Stevens 2012), it is timely to evaluate whether a rigorous quantitative regional analysis of preexisting charred weed data can provide insights into the regional movement of crops, or whether future research should focus on the application of these isotopic techniques.

Households are widely understood as the building blocks of Iron Age society (Hill 2011). It is now accepted that households and communities did not form independent productive units in later prehistory, but were linked through various social and material exchanges (Davis 2013; Moore 2007). Pioneering archaeobotanical studies at Danebury, a large multivallate Iron Age hillfort in central-southern Britain, made a key contribution to the idea that hillforts acted as places for the redistribution of cereals between surrounding settlements (Cunliffe 1984). Amongst the weed seeds identified alongside charred cereal grains from storage pits, Carex spp., Eleocharis palustris and Mentha sp., were defined as a group of damp ground taxa, and Chrysanthemum segetum and Rumex acetosella were classified as acid ground taxa (Jones, M. 1984: 488). Due to the distributions of soil types in the surrounding region, Jones suggested that crops were grown on both damp riverside loams and acidic gravel terraces associated with the nearby River Test, drawing the conclusion that "the hillfort was receiving cereal crops from throughout its territory at all stages of its development" (Jones, M. 1984: 493). This finding was incorporated into Cunliffe's redistributive model of Iron Age society (Cunliffe 1984). No quantitative analysis of the crop or weed content of specific samples was undertaken and Jones considered the weed seeds to have been derived from several harvests (Jones 1984: 49). Without first establishing that the weeds and crop items within charred samples derived from the same activity, it is possible that the weeds were introduced to the samples via other activities, such as dung (Charles 1998) or turf burning (Hall 2003). Also without first establishing that the charred cereals and weeds derive from the same crop-processing stage, it cannot be known whether any variation in the types of weed seeds present is derived from contrasts in past field conditions, or is taphonomic in origin (Bogaard 2004: 64-66). Despite the limitations of Jones' 
analysis, his conclusions continue to be repeated (Davis 2013: 367; Jones 1985: 120; Jones 2007: 144; Lightfoot and Stevens 2012: 657).

The development of oppida in Late Iron Age southern Britain from $100 \mathrm{BC}$ onwards is heavily debated, with origins identified in both external and internal factors (Haselgrove 1982; Pitts 2010). The movement of cereal crops across the landscape has occasionally been built into narratives of settlement development. For instance, it has been suggested that agricultural produce was sent from agricultural settlements on the Hampshire Downs to the oppida at Chichester and Silchester (Cunliffe 2012: 19; Sharples 2010: 173). Furthermore, the pastoral, rather than arable, activities taking place at oppida have been emphasised (Creighton 2000: 72; Moore 2012: 411; Lodwick 2017). The arrival of the Roman military in AD43, and the subsequent development of towns, resulted in much larger non-agricultural populations, requiring the import of plant and animal foods from rural areas in Britain and beyond. However the source of these cereals has only been debated on a foreign versus local basis (Fulford 2000; Sauer 2002), with the food supply for towns presumed to originate from the surrounding hinterlands (Roskams 1999). Tested techniques to source charred cereal remains would enable a more detailed discussion of the sources of cereals for oppida, the military and urban populations.

Plant taxa with different ecological characteristics grow under different environmental conditions (Jones et al. 2010: 494). Whilst some modern studies of the floristic composition of arable fields have shown that variations in cultivation intensity has a greater effect on the weed flora than any geographical variation (Jones et al. 1999), a recent weed survey of cereal farming in Haute Provence, France, showed that variation in climate and soil types within the study area had a greater influence on floristic variation than differences in cultivation practices (Bogaard et al. 2016). The floristic composition of arable fields could provide insights into the location where cereals were grown, and hence any regional movement of crops in Iron Age and Roman Britain. For instance, the analysis of charred plant remains from Iron Age Ashkelon, Israel, used the modern day distributions of selected plant taxa to identify the location of past cereal fields (Weiss and Kislev 2004). Considering the substantial dataset of charred plant remains available from Iron Age and Roman Britain (Van der Veen et al. 2007), and recent calls for more detailed analysis of arable weeds (Van der Veen 2014), it is timely to undertake such quantitative analysis of arable weed seeds found alongside charred cereal remains in order to assess whether the geographical origin of cereal crops can be established. This paper first identifies charred cereal samples representing unmixed crop-processing by-products which can provide a good reflection of the field conditions in which the cereal crops were grown, despite the retention of some large weeds seeds, such as Agrostemma githago, with the harvested crop. Autecological values of weed taxa present in these samples are then used to evaluate field 
conditions, and the resulting finds discussed in terms of the archaeobotanical and archaeological context.

\section{Material and methods}

The selected case study region is focussed on the Late Iron Age oppidum and Roman town of Silchester (Calleva Atrebatum) in central-southern Britain. Late Iron Age Silchester was a territorial oppidum, with an occupation area of $32 \mathrm{ha}$ within a series of enclosures. Following the Claudian invasion, Silchester became a civitas capital (Fulford and Timby 2000). A radius of $40 \mathrm{~km}$ around Silchester was selected as the regional study area, extending north to the river terraces of the Upper Thames Valley at Abingdon, south to Winchester, west to the Hampshire Downs at Basingstoke and east to Staines (Fig. 1). The selected region contains contrasting geological areas, where differences in arable weed seeds can be expected, and numerous archaeological sites spanning the Iron Age and Roman period, when the movement of cereal crops across the landscape has been hypothesised to have taken place.

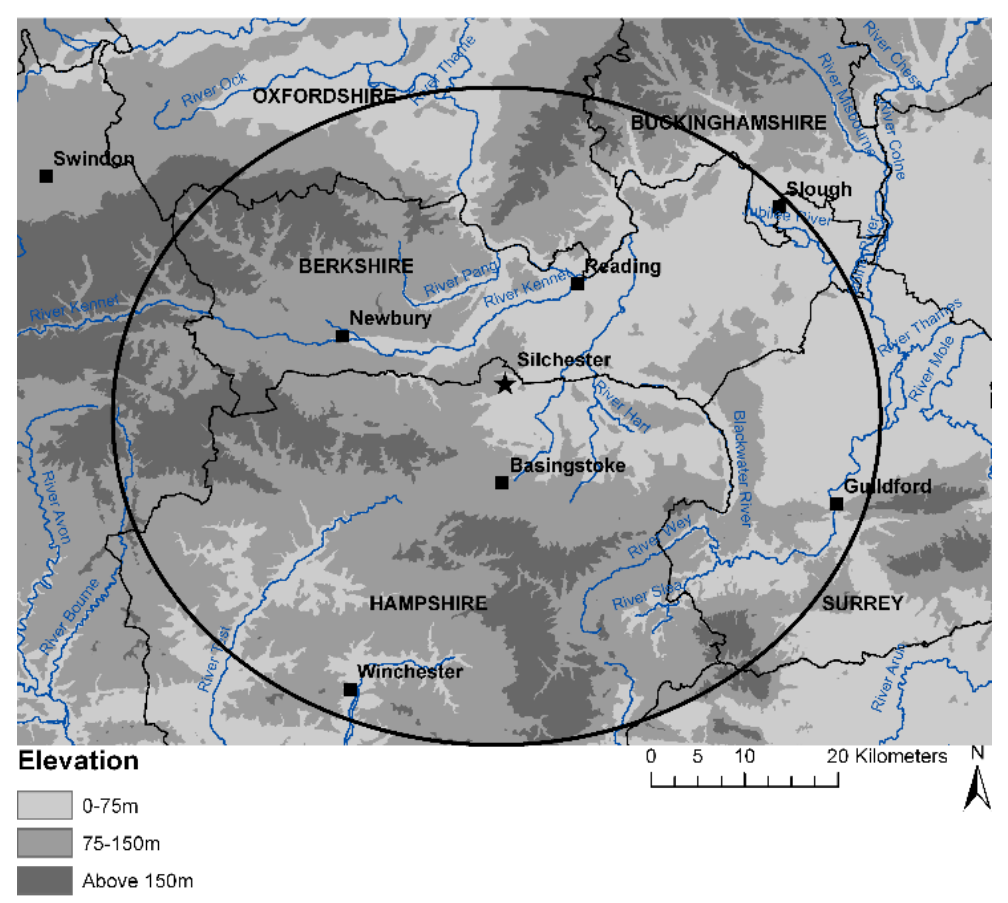

Fig. 1 Modern location of Silchester and the regional study area. Contains OS data @ Crown copyright and database right 2017.

This area falls within the temperate-oceanic climatic group (Kottek et al. 2006). There is little regional variation in precipitation, with average rainfall of $60-100 \mathrm{~mm}$ in January, and $40-80 \mathrm{~mm}$ in July (Met Office 2015). The most significant geographical variation is in basal and superficial geology. Silchester is sited on a gravel terrace of the river Kennet, overlying an area of tertiary deposits consisting of various clays and sands (Mathers and Smith 2000), referred to as the Thames Basin Heaths (Natural England 2014). The varied geology of this region results in areas of free draining acidic soils, heavy stony soils and free draining loam soils (Branch and 
Green 2004). To the northwest is a band of cretaceous chalk, the Berkshire Downs, continuing to the south of Silchester as the Hampshire Downs. In places the chalk is capped with boulder clay deposits (Cunliffe and Poole 2000). These areas have thin calcareous soils today. The river Thames flows from west to east through the study area. The Upper Thames Valley, to the north of the Goring Gap, consists of gravel terraces composed of limestone gravel, bounded by clay soils. The floodplain of the Mid Thames Valley, to the south, is also covered by alluvial soils overlying gravel terraces composed of flint, producing acidic free draining soils (Booth et al. 2007: 7). Hence there are three distinct areas of sandy acidic and clay soils (Thames Basin Heaths), calcareous soils (Hampshire Downs) and alluvial soils overlying gravel (Thames Valley).

This region has undergone intensive archaeobotanical investigation since the late 1970 s due to both excavations in advance of gravel extraction and urban expansion (Robinson 1992), and research excavations on the Hampshire Downs (Campbell 2000a; 2008a). The charred plant remains from Silchester originate from the Late Iron Age phases of occupation at Insula IX (Lodwick 2015). Regional archaeobotanical data were collected from published sources and available grey-literature from contexts dated by ceramics and stratigraphy to the Middle Iron Age - Late Roman period. Semi-quantified samples and assemblages where modern contamination had been highlighted were excluded (Pelling et al. 2015).

This process resulted in 987 charred samples from 159 site phases (Table 1, ESM Table 1). Several steps of data standardisation of cereals and wild taxa were undertaken (ESM Table 2), due to the necessity of producing archaeobotanical taxa which were frequent enough in the dataset to be included in correspondence analysis (5\%). Seeds identified to genus level were proportionately reallocated to the species within that genus present in the same sample. Samples from the same contexts were combined. Triticum spelta (spelt wheat) and $T$. dicoccum (emmer wheat) were combined, as they are both glume wheats which behave the same way during crop-processing and spelt wheat was always the dominant glume wheat within samples. Samples with fewer than 100 crop and arable items per sample were removed in order to retain those with a higher likelihood of reflecting the original sample (Van der Veen and Fieller 1982). 
Table 1 Summary of number of regional site phases used in this study. The number of charred samples are indicated in brackets.

\begin{tabular}{|l|c|c|c|c|}
\hline & $\begin{array}{c}\text { Hampshire } \\
\text { Downs }\end{array}$ & $\begin{array}{c}\text { Middle Thames } \\
\text { Valley }\end{array}$ & $\begin{array}{c}\text { Thames Basin } \\
\text { Heaths }\end{array}$ & $\begin{array}{c}\text { Upper Thames } \\
\text { Valley }\end{array}$ \\
\hline Mid Iron Age & $22(131)$ & $4(11)$ & $3(8)$ & $11(162)$ \\
\hline Late Iron Age & $10(46)$ & $1(5)$ & $2(24)$ & $4(13)$ \\
\hline Early Roman & $15(73)$ & $9(80)$ & $1(52)$ & $10(80)$ \\
\hline Mid Roman & $10(18)$ & $5(20)$ & $2(4)$ & $3(14)$ \\
\hline Late Roman & $13(75)$ & $6(19)$ & $2(6)$ & $6(51)$ \\
\hline Roman & $6(20)$ & $4(6)$ & $1(2)$ & $4(11)$ \\
\hline Iron Age/Roman & $2(5)$ & $1(2)$ & $0(0)$ & $2(49)$ \\
\hline
\end{tabular}

Samples for which the crop-content (grain and glume bases for glume wheats; grain and rachis for free-threshing cereals) was composed of at least $70 \%$ of one crop type (glume wheat or free-threshing cereal) were classified as unmixed samples. Each sample was assigned to a crop-processing stage based initially on ratios (Table 2). Discriminant analysis was undertaken following Jones (1991). Weed seeds were categorised based on characteristics relevant to their behaviour during crop-processing (small vs big, headed vs free, heavy vs light) (Jones, G. 1984; Van der Veen 1992), with a size boundary of $2 \mathrm{~mm}$ in width set between 'small' and 'big' weed seeds. The discriminant scores were obtained by running a discriminant analysis in IBM SPSS Statistics Version 21 using the Amorgos ethnographic data as control groups. Archaeobotanical samples were entered that contained at least ten seeds that had been categorised into one of Jones' groups. These were then classified using the discriminant scores. $P$ values of $\geq 0.9$ were classified as high probability results (Bogaard 2011: 155). The results from ratio and discriminant analysis have been combined to assign a single crop-processing stage to each sample (ESM Table 3). On some occasions, ratio analysis classified a sample as a fine-sieve by-product (FSBP), and DA produced the result of fine-sieve product (FSP). Such samples are often described as 'pre-sieved FSBP'. These most likely represent fine-sieve by-products from the dehusking of spikelets which had previously been sieved to remove most small weeds. The possibility of 'pre-sieved' spikelets was raised initially by Stevens (Stevens 2003: 69-71), and the potential variation between clean spikelets and un-sieved spikelets has been supported (Bogaard 2011: 152; Van der Veen and Jones 2006: 110). 
Table 2 Crop-processing analysis criteria and results.

\begin{tabular}{|l|l|l|l|}
\hline $\begin{array}{l}\text { Crop-processing } \\
\text { stage }\end{array}$ & Sample contents & $\begin{array}{l}\text { Results of } \\
\text { discriminant } \\
\text { analysis }\end{array}$ & Number of samples \\
\hline $\begin{array}{l}\text { Barley fine-sieve } \\
\text { product }\end{array}$ & $\begin{array}{l}\text { Over } 70 \% \text { of crop items barley. } \\
\text { Ratio of barley grain/barley rachis } \\
>0.5 .\end{array}$ & FSP & 24 \\
\hline $\begin{array}{l}\text { Spelt wheat fine-sieve } \\
\text { product }\end{array}$ & $\begin{array}{l}\text { Over } 70 \% \text { of crop items spelt or } \\
\text { emmer wheat. } \\
\text { Ratio of spelt grain/spelt glume } \\
\text { bases }>1.5 .\end{array}$ & FSBP & 34 \\
\hline Spelt wheat spikelets & $\begin{array}{l}\text { Over } 70 \% \text { of crop items spelt or } \\
\text { emmer wheat. } \\
\text { Ratio of spelt grain/spelt glume } \\
\text { bases } 0.8-1.5 .\end{array}$ & FSBP & 3 \\
\hline $\begin{array}{l}\text { Spelt wheat fine-sieve } \\
\text { by-product }\end{array}$ & $\begin{array}{l}\text { Over } 70 \% \text { of crop items spelt or } \\
\text { emmer wheat. } \\
\text { Ratio of spelt grain/spelt glume } \\
\text { bases < 0.8. }\end{array}$ & FSBP & 54 \\
\hline Mixed & $\begin{array}{l}\text { Under } 70 \% \text { of crop items of a single } \\
\text { crop type. }\end{array}$ & various & 54 \\
\hline
\end{tabular}

Crop items were not included in the analysis, leaving only the arable taxa. Correspondence analysis was performed using CANOCO version 4.5 and results plotted using CANODRAW version 4.1 (Ter Brak and Ŝmilauer 2002). Samples were classified by archaeological and geographical factors, including National Character Area groupings (Natural England 2014). Nomenclature is based on Stace (2010). The ecological attributes of each archaeobotanical taxa were established from regional (Brewis et al. 1996; Crawley 2005) and national flora (Stace 2010) and the PLANTATT database (Hill et al. 2004). This technique is a form of autecology; extrapolating the tolerance of modern weed taxa to certain environmental conditions to archaeobotanical weed taxa. The risk that the ecology of individual taxa will have shifted through time (Bogaard 2004: 7) was lessened by the incorporation of the majority of weed taxa present per sample into the correspondence analysis (Van der Veen 1992: 108).

\section{Results}

\subsection{Sample selection}

Of the 291 samples entered into ratio and discriminant analysis (Table 2) the most common crop-processing stage identified was spelt fine-sieving products and pre-sieved fine-sieve byproducts, which contained a very restricted range of arable weeds, mainly Avena spp., Bromus spp., Fallopia convolvulus and Galium aparine. These taxa have limited affinities for different geological areas and, as predicted, the plot of this correspondence analysis (Fig 2.) 
demonstrated that the main variation was between autumn sown (characterised by Bromus spp.) and spring sown (characterised by Avena spp.) crops (Bogaard et al. 2001; Campbell 2000a). Thus, spelt fine-sieve by-products were selected as the unit for the regional cropsourcing analysis, due to the wider range of archaeobotanical weed taxa present. Samples from 16 sites were classified as unmixed spelt fine-sieve by-products, which contained spelt glume bases and small free and heavy arable weed seeds. These sites are listed in Table 3 and sample level meta data is provided in ESM Table 3.

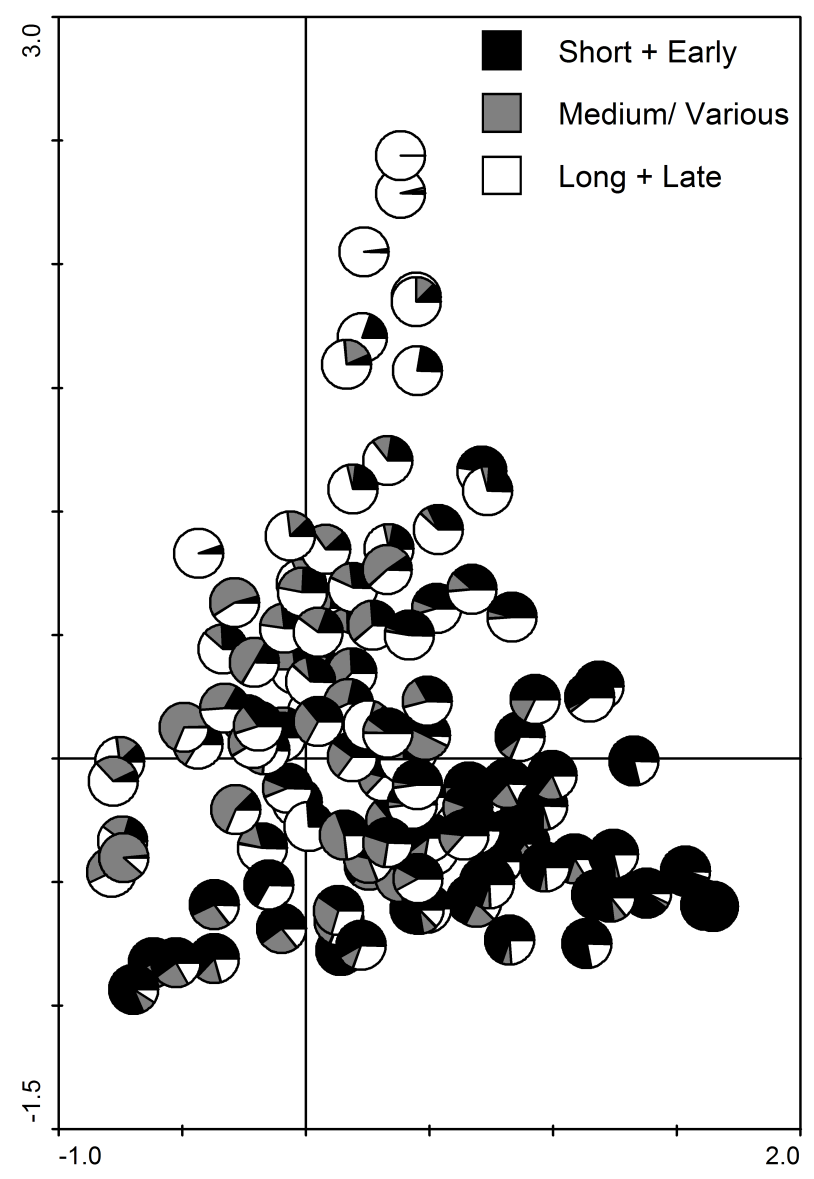

Fig 2. Correspondence analysis plot of arable weeds from samples classified as spelt FSP, sample pies classified by flowering onset and duration. 1st (horizontal) and 2nd (vertical) axis. 132 samples, 29 taxa.

Table 3 List of sites with samples identified as spelt fine-sieve by-products which were utilised in the correspondence analysis. 


\begin{tabular}{|c|c|c|c|c|c|c|}
\hline Site & Location & Period & Site type & $\begin{array}{l}\text { Number } \\
\text { of } \\
\text { samples }\end{array}$ & Abbreviation & Reference \\
\hline Houghton Down & $\begin{array}{l}\text { Hampshire } \\
\text { Downs }\end{array}$ & Mid Iron Age & Enclosed settlement & 2 & HTD & Campbell 2008d \\
\hline Lains Farm & $\begin{array}{l}\text { Hampshire } \\
\text { Downs }\end{array}$ & Middle Iron Age & Enclosed settlement & 1 & LNF & Carruthers 1991 \\
\hline Rowbury Farm & $\begin{array}{l}\text { Hampshire } \\
\text { Downs }\end{array}$ & Middle Iron Age & Enclosed settlement & 1 & RWF & Campbell 2008e \\
\hline Suddern Farm & $\begin{array}{l}\text { Hampshire } \\
\text { Downs }\end{array}$ & Middle Iron Age & Enclosed settlement & 1 & SDF & Campbell 2000b \\
\hline $\begin{array}{l}\text { Abingdon } \\
\text { Vineyard }\end{array}$ & $\begin{array}{l}\text { Upper } \\
\text { Thames } \\
\text { Valley }\end{array}$ & Middle Iron Age & Oppidum & 4 & AVY & Stevens 1996 \\
\hline Grateley & $\begin{array}{l}\text { Hampshire } \\
\text { Downs }\end{array}$ & Late Iron Age & Enclosure & 1 & GRT & Campbell 2008c \\
\hline $\begin{array}{l}\text { Silchester, } \\
\text { Insula IX }\end{array}$ & $\begin{array}{l}\text { Thames Basin } \\
\text { Heaths }\end{array}$ & Late Iron Age & Oppida & 3 & SIX & Lodwick 2015 \\
\hline Thruxton & $\begin{array}{l}\text { Hampshire } \\
\text { Downs }\end{array}$ & Late Iron Age & Enclosed settlement & 1 & TRX & Summers and Campbell 2008 \\
\hline $\begin{array}{l}\text { Abingdon } \\
\text { Vineyard }\end{array}$ & $\begin{array}{l}\text { Upper } \\
\text { Thames } \\
\text { Valley }\end{array}$ & Iron Age/Roman & Oppidum & 3 & $A V Y$ & Stevens 1996 \\
\hline $\begin{array}{l}\text { Abingdon } \\
\text { Vineyard }\end{array}$ & $\begin{array}{l}\text { Upper } \\
\text { Thames } \\
\text { Valley }\end{array}$ & Early Roman & Oppidum & 7 & AVY & Stevens 1996 \\
\hline All Souls Farm & $\begin{array}{l}\text { Middle } \\
\text { Thames } \\
\text { Valley }\end{array}$ & Early Roman & Open settlement & 2 & ASF & McKenna 2012 \\
\hline $\begin{array}{l}\text { Brighton Hill } \\
\text { South }\end{array}$ & $\begin{array}{l}\text { Hampshire } \\
\text { Downs }\end{array}$ & Early Roman & Enclosed settlement & 1 & $\mathrm{BHS}$ & Carruthers 1995 \\
\hline $\begin{array}{l}\text { Denchworth } \\
\text { Road }\end{array}$ & $\begin{array}{l}\text { Upper } \\
\text { Thames } \\
\text { Valley }\end{array}$ & Early Roman & Roadside settlement & 2 & DWR & Fairbairn and Austin 2001 \\
\hline $\begin{array}{l}\text { Winchester } \\
\text { Northgate } \\
\text { House. }\end{array}$ & $\begin{array}{l}\text { Hampshire } \\
\text { Downs }\end{array}$ & Early Roman & Major town & 1 & WNH & Carruthers 2011 \\
\hline $\begin{array}{l}\text { Denchworth } \\
\text { Road }\end{array}$ & $\begin{array}{l}\text { Upper } \\
\text { Thames } \\
\text { Valley }\end{array}$ & Mid Roman & Roadside settlement & 1 & DWR & Fairbairn and Austin 2001 \\
\hline Perry Oaks & $\begin{array}{l}\text { Middle } \\
\text { Thames } \\
\text { Valley }\end{array}$ & Middle Roman & Enclosed settlement & 1 & PRO & Carruthers 2010 \\
\hline Grateley & $\begin{array}{l}\text { Hampshire } \\
\text { Downs }\end{array}$ & Middle Roman & Villa & 1 & GRT & Campbell 2008c \\
\hline Grateley & $\begin{array}{l}\text { Hampshire } \\
\text { Downs }\end{array}$ & Late Roman & Villa & 1 & GRT & Campbell 2008c \\
\hline Bagnor Road & $\begin{array}{l}\text { Thames Basin } \\
\text { Heaths }\end{array}$ & Late Roman & Rural settlement & 3 & BGR & Ede 2000 \\
\hline $\begin{array}{l}\text { Barton Court } \\
\text { Farm }\end{array}$ & $\begin{array}{l}\text { Upper } \\
\text { Thames } \\
\text { Valley }\end{array}$ & Late Roman & Villa & 2 & $\mathrm{BCF}$ & Jones and Robinson 1984 \\
\hline
\end{tabular}




\begin{tabular}{|l|l|l|l|l|l|l|}
\hline $\begin{array}{l}\text { Denchworth } \\
\text { Road }\end{array}$ & $\begin{array}{l}\text { Upper } \\
\text { Thames } \\
\text { Valley }\end{array}$ & Late Roman & Roadside settlement & 1 & DWR & Fairbairn and Austin 2001 \\
\hline Fullerton & $\begin{array}{l}\text { Hampshire } \\
\text { Downs }\end{array}$ & Late Roman & Villa & 1 & FLT & Campbell 2008b \\
\hline Marnel Park & $\begin{array}{l}\text { Hampshire } \\
\text { Downs }\end{array}$ & Roman & Rural settlement & 4 & Pelling 2009 \\
\hline
\end{tabular}

Compared to the large number of site phases consulted (159), and the large dataset of samples obtained (987), a relatively small number of samples (54 before the removal of outliers) were entered into the analysis. The relatively low number of samples identified as spelt FSBPs is due to two factors. First, the character of the archaeobotanical record in this period and region. Densities of charred plant remains are often low and sample size has not always been adjusted to account for this, meaning samples contain insufficient numbers of items, and the composition of many samples are mixtures of crops, or fine-sieve products and pre-sieved fine-sieve by-products where small weeds are absent (Table 2). Second, practices of sampling and analysis have often resulted in relatively small numbers of samples per site, with low numbers of items $(<100)$ per sample (Van der Veen et al. 2007).

\subsection{The arable weeds present}

50 archaeobotanical weed taxa were present in these samples, listed in Table 4. The majority of these taxa, such as Bromus subg. Bromus and Avena spp. do not have strong tolerances for particular geological areas and differences in their quantities reflect variation in sowing time (Bogaard et al. 2001; Campbell 2000a). However, some taxa do have geological preferences, such as those found mainly on calcareous soils. Valerianella dentata is an annual herb, found today on cornfields and rough ground. It is widespread and locally frequent on calcareous soils, occurring rarely on other soil types (Brewis et al. 1996: 227; Crawley 2005: 800). Anthemis arvensis is an annual herb present on arable land, waste and rough ground (Stace 2010: 755). Locally, it is frequent on calcareous areas in Berkshire and Hampshire (Crawley 2005: 963), only occurring casually on sandy soils (Brewis et al. 1996: 244). Hyoscyamus niger and Sherardia arvensis are both found on calcareous grassland. Other arable weeds are calciphobus. Spergula arvensis is an annual herb of acidic sandy cultivated ground (Stace 2010: 467), and locally avoids pure chalk soil (Brewis et al. 1996: 118). Rumex acetosella is a perennial herb found on cultivated ground, acidic grassland and heathland (Stace 2010: 446). In chalk grassland, it is restricted to ant-hills and superficial acidic deposits (Brewis et al. 1996: 122).

One taxon, Anthemis cotula, an annual herb of arable land, waste and rough ground (Stace 2010: 755), is most common on heavy clay and clay loam soils (Kay 1971a). Anthemis cotula 
is often seen as an indicator of the past cultivation of heavy clay soils (Jones, 1981). However, it can occur on clay-with-flints overlying chalk, and on heavier chalk soils (Kay 1971, 625). Today it is common on both clay and chalk soils in northern Hampshire (Brewis et al. 1996: 244), and used to be locally frequent on arable fields on the chalk in Berkshire (Crawley 2005: 964). Other taxa are not tolerant of clay soil conditions. Papaver argemone (prickly poppy) is an annual herb of dry arable fields and waste ground, but only on light soils (Stace, 2010: 88), and locally on chalk or sand soils (Brewis et al. 1996: 105; Crawley 2005: 361). Aphanes arvensis is an annual herb, found on cultivated and open ground which is well drained (Stace 2010: 267). Locally, A. arvensis has been reported as absent from clay soils (Crawley 2005: 587) and found especially on basic soils (Brewis et al. 1996: 163). Arenaria serpyllifolia grows only on well-drained soils (Stace 2010: 456). Rumex acetosella is restricted to sandy and gravelly soils (Brewis et al. 1996: 122) and Spergula arvensis also avoids damp clay soils (Crawley 2005: 414). Overall, it must be stressed that these are not strict geological tolerances but tendencies for plants to be more common on certain soil types.

Table 4 Summary of nomenclature, and the tolerance of calcareous and clay soils of the arable weed taxa included in the analysis.

\begin{tabular}{|c|c|c|c|c|}
\hline Taxa & Common name & $\begin{array}{l}\text { Calcareous } \\
\text { soils }\end{array}$ & Clay soils & Key references \\
\hline Agrostemma githago L. & Corncockle & - & - & Firbank 1988 \\
\hline Anthemis arvensis $\mathrm{L}$. & Corn Chamomile & Yes & - & Kay 1971a \\
\hline Anthemis cotula L. & Stinking Mayweed & - & Yes & Kay $1971 b$ \\
\hline Aphanes arvensis $\mathrm{L}$. & Parsley-piert & - & No & \\
\hline Arenaria serpyllifolia L. & Thyme-leaved Sandwort & - & No & \\
\hline Atriplex sp. & Oraches & - & - & \\
\hline Avena sp. & Oats & - & - & \\
\hline Brassica sp. & Cabbages/Mustards & - & - & \\
\hline Bromus Subg. Bromus & Bromes & - & - & \\
\hline Carex sp. & Sedges & - & - & \\
\hline Centaurea cyanus L. & Cornflower & - & - & \\
\hline Cerastium sp. & Mouse-ears & - & - & \\
\hline Chenopodium album L. & Fat-hen & - & - & \\
\hline $\begin{array}{l}\text { Eleocharis palustris (L.) Roem. \& } \\
\text { Schult. }\end{array}$ & Common Spike-rush & - & - & \\
\hline Fallopia convolvulus L. & Black-bindweed & - & - & \\
\hline Fumaria sp. & Fumitories & - & - & \\
\hline Galium album/verum/palustre & Bedstraws & - & - & \\
\hline Galium aparine L. & Cleaver & - & - & \\
\hline
\end{tabular}




\begin{tabular}{|c|c|c|c|c|}
\hline Hyoscyamus niger $\mathrm{L}$. & Henbane & Yes & - & \\
\hline Juncus indet. & Rush & - & - & \\
\hline Lapsana communis L. & Nipplewort & - & - & \\
\hline Medicago Iupulina L. & Black Medick & - & - & \\
\hline Medicago/Trifolium & Medicks/Clovers & - & - & \\
\hline Montia fontana $\mathrm{L}$. & Blinks & - & - & \\
\hline Odontites vernus (Bellardi) Dumort. & Red Bartsia & - & - & \\
\hline Papaver argemone $\mathrm{L}$. & Prickly Poppy & - & No & \\
\hline Papaver rhoeas type & Common Poppy & - & - & \\
\hline Papaver somniferum $\mathrm{L}$. & Opium Poppy & - & - & \\
\hline Persicaria lapathifolia/maculosa & Pale Persicaria/Redshank & - & - & \\
\hline Plantago lanceolata/media & Ribwort/Hoary Plantain & - & - & \\
\hline Plantago major L. & Greater Plantain & - & - & \\
\hline Polygonum aviculare agg. & Knotgrass & - & - & \\
\hline Potentilla sp. & Cinquefoils & - & - & \\
\hline Prunella vulgaris $\mathrm{L}$. & Selfheal & - & - & \\
\hline Ranunculus acris/repens/bulbosus & Buttercups & - & - & \\
\hline Rumex acetosella agg. & Sheep's Sorrel & No & No & \\
\hline Rumex sp. & Docks & - & - & \\
\hline Sherardia arvensis $\mathrm{L}$. & Field Madder & Yes & - & \\
\hline Silene sp. & Campions & - & - & \\
\hline Spergula arvensis $\mathrm{L}$. & Corn Spurrey & No & No & New 1961 \\
\hline Stellaria graminea/palustris & Lesser/Marsh Stichwort & - & - & \\
\hline Stellaria media (L.) Vill. & Common Chickweed & - & - & \\
\hline Torilis sp. & Hedge-parsleys & - & - & \\
\hline Trifolium sp. & Clovers & - & - & \\
\hline Tripleurospermum inodorum L. & Scentless Mayweed & - & - & \\
\hline Urtica dioica $\mathrm{L}$. & Common Nettle & - & - & \\
\hline Urtica urens L. & Small Nettle & - & - & \\
\hline Valerianella dentata L. & Narrow-fruited Cornsalad & Yes & - & - \\
\hline Veronica arvensis $\mathrm{L}$. & Wall Speedwell & - & - & \\
\hline Vicia/Lathyrus & Vetch/Peas & - & - & \\
\hline
\end{tabular}




\subsection{Comparison of the arable weed content}

45 samples and 50 archaeobotanical taxa were entered into correspondence analysis. The samples were distributed along both axes (Fig. 3). Samples from sites located on the Hampshire Downs are located towards the positive end of axis 1 or the positive end of axis 2 . Samples from the Mid Thames and Thames Basin Heaths are located towards the negative end of Axis 1, and most samples from the Upper Thames are located towards the negative ends of both axes. No classification by site type or period explained the variation in this plot (ESM Fig 1 and 2). Sites were placed into one of three groups consisting of individual or combined National Character Areas with broadly similar geographic characteristics, and this classification did explain the variation (Fig. 3).

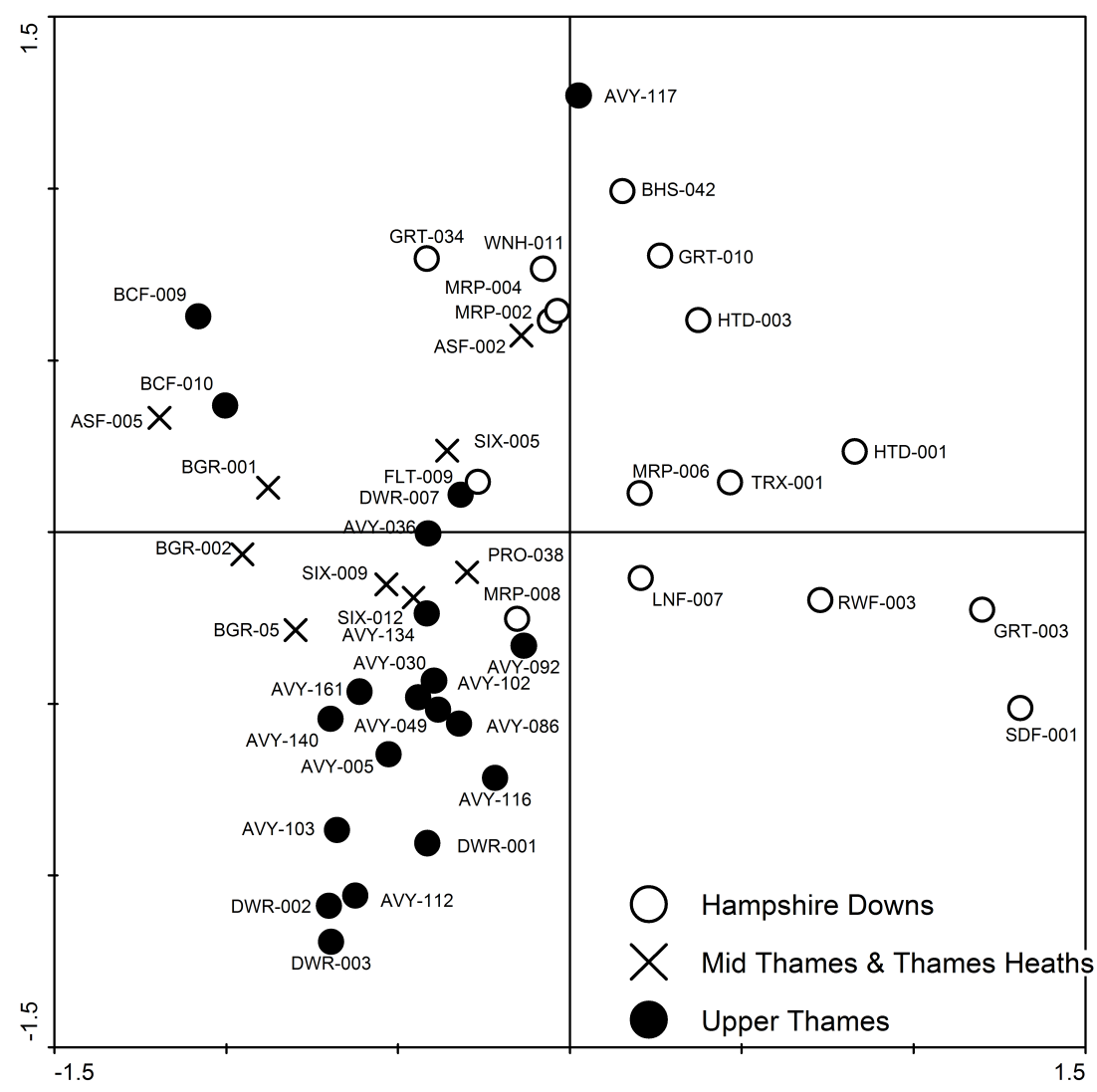

Fig. 3 Correspondence analysis plot of arable weeds from regional spelt FSBP samples, samples classified by NCA (National Character Area). 1st (horizontal) and 2nd (vertical) axis. 45 samples, 50 taxa. SIX refers to samples from Silchester Insula IX.

The correspondence analysis plot of arable weeds (Fig 4) shows distinctive groupings of taxa which map on to the sample plot (Fig 3), with several taxa located near the origin. Some samples from the Hampshire Downs are located towards the positive end of axis 1 and are characterised by Anthemis arvensis, Cerastium sp., Papaver argemone, Papaver rhoeas type, Urtica dioica, Valerianella dentata. Other samples from the Hampshire Downs are located towards the positive end of axis 2 and are characterised by Brassica sp., Papaver 
somniferum, Rumex sp. and Silene sp. A range of taxa plot in between. Samples from the Mid Thames Valley and the Thames Basin Heath are characterised by Agrostemma githago,

Anthemis cotula, Avena sp., Centaurea cyanus, Eleocharis palustris, and Odontites vernus.

Samples from the Upper Thames are characterised by Chenopodium album, Galium

album/verum/palustre, Juncus indet., Montia fontana, Persicaria lapathifolia/maculosa,

Rumex acetosella, Spergula arvensis, Trifolium sp. and Vicia/Lathyrus. The fact that variation on axis 1 is explained successfully by geographical location means that groups of weed taxa are associated with different broad soil types.

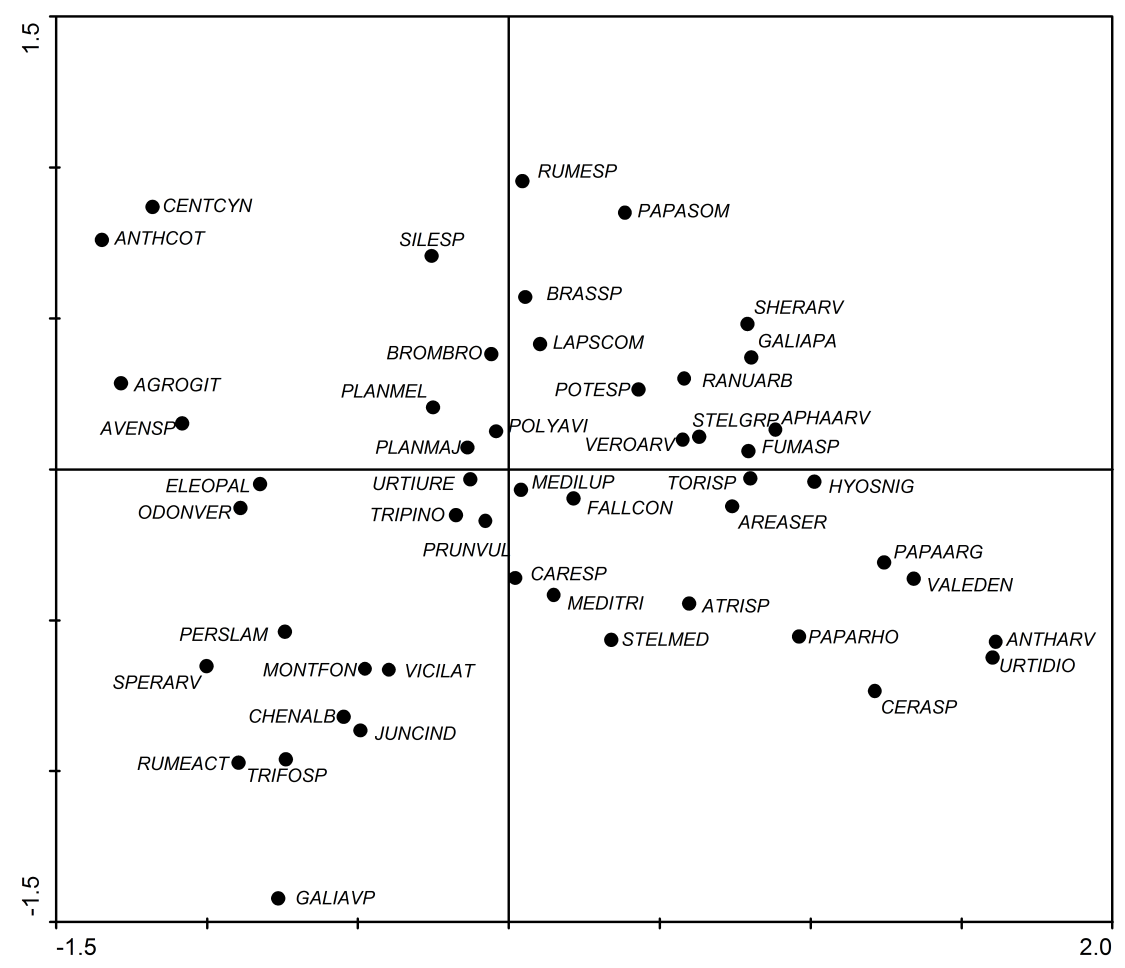

Fig. 4 Correspondence analysis plot of arable weeds from regional spelt FSBP samples, taxa plot. 1st (horizontal) and 2nd (vertical) axis. 45 samples, 50 taxa. $S$ indicates the location of samples from Silchester.

When the composition of each sample is displayed as a pie chart, this pattern is more visible. Samples located towards the positive end of axis 1 and 2 contain taxa associated with calcareous soils (Anthemis arvensis, Hyoscyamus niger, Sherardia arvensis, Valerianella dentata) (Fig. 5), and $0-12 \%$ seeds from taxa which grow on light soils (chalk or sand) rather than clay soils (Fig. 6). Samples located towards the negative end of axis 2 contain $0-29 \%$ seeds from taxa that are rarely found on calcareous soils today (Rumex acetosella and Spergula arvensis) (Fig. 6). Samples located towards the negative end of axis 1 contain 1-25\% seeds from taxa that are clay tolerant (Anthemis cotula) (Fig. 5). 


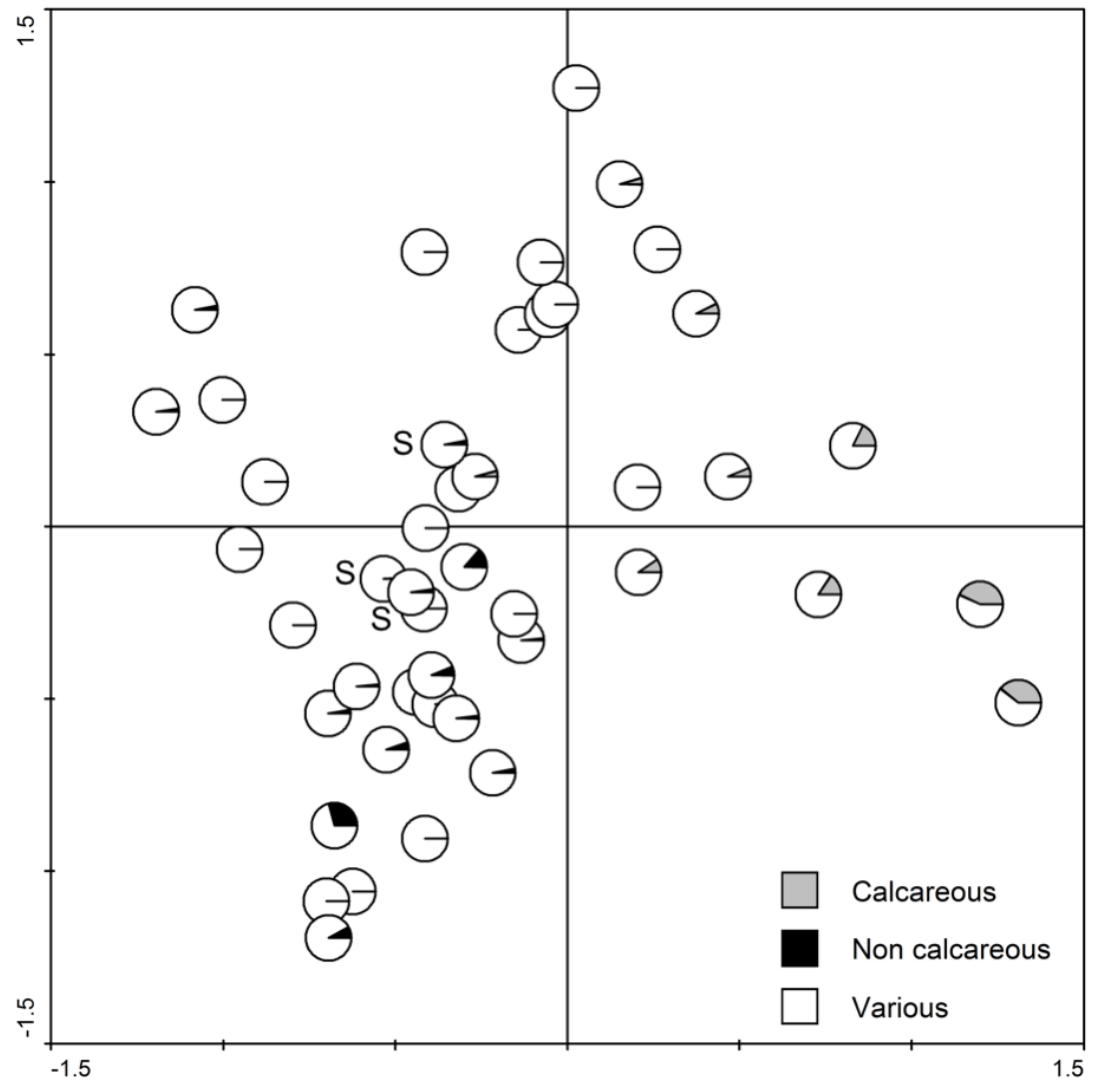

Fig. 5 Correspondence analysis plot of arable weeds from regional spelt FSBP samples, taxa classified by preference for calcareous soil. 1st (horizontal) and 2nd (vertical) axis. 45 samples, 50 taxa. $\mathrm{S}$ indicates the location of samples from Silchester. 


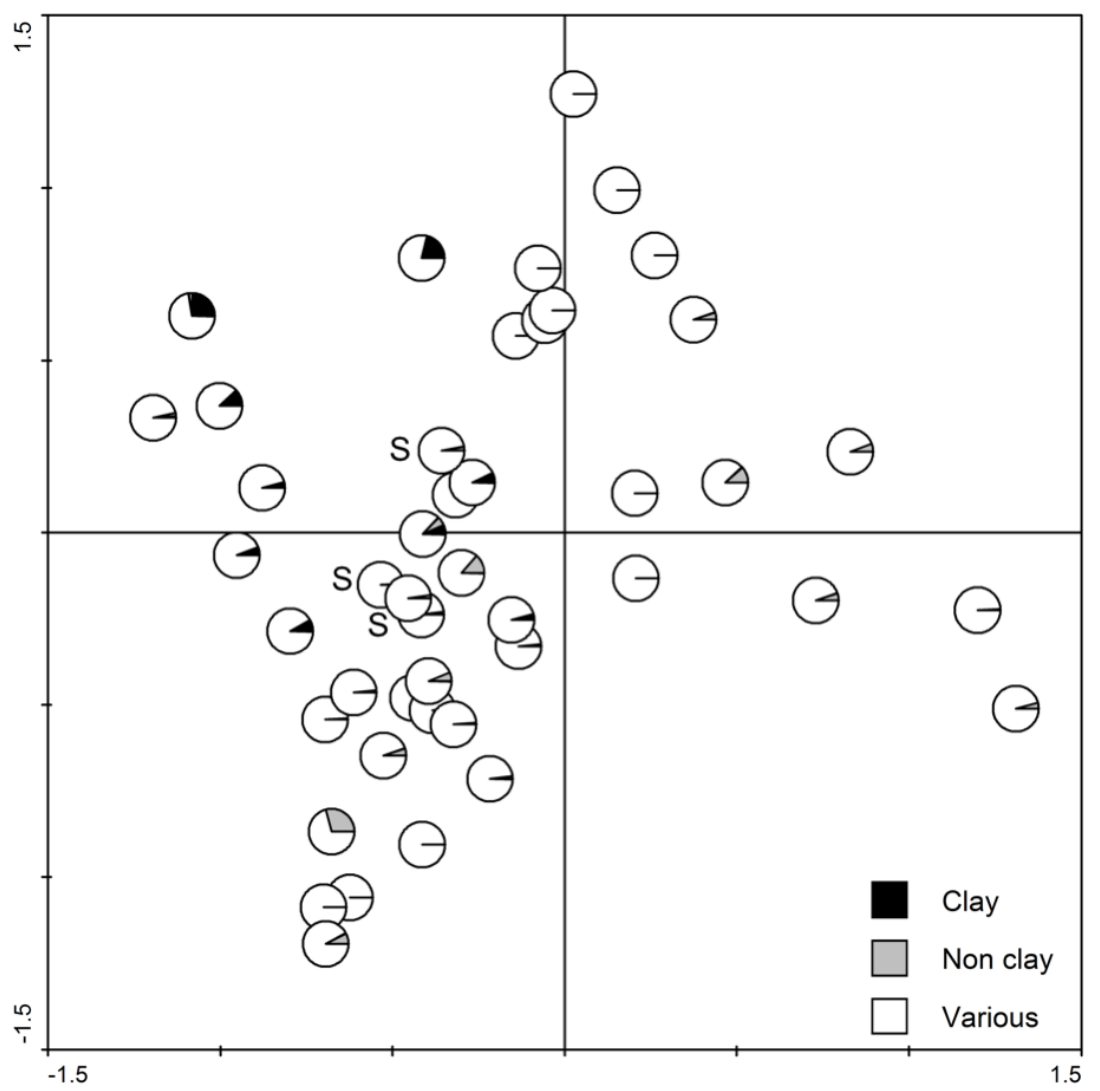

Fig. 6 Correspondence analysis plot of arable weeds from regional spelt FSBP samples, taxa classified by preference for clay soil. 1st (horizontal) and 2nd (vertical) axis. 45 samples, 50 taxa.

Now that it has been established that the arable weeds present within spelt wheat fine-sieve by-products are broadly distinguished by their geographical origin, the implications for individual sites can be assessed. Samples from Silchester Insula IX were located close to the origin of axis 2 (Fig. 3). This reflects the mixed geology of the area surrounding Silchester, with various clay, sandy, and stony soils. Whilst this cannot rule out the option that spelt wheat was being transported to Late Iron Age Silchester from agricultural settlements located on similar geologies, the arable weeds present alongside spelt fine-sieving by-products at Silchester are not consistent with those found alongside crop remains in samples from settlements located on the calcareous soils of the Hampshire Downs. The number of samples from Late Iron Age Silchester Insula IX in the reduced dataset is only three, and there are few contemporary sites from the surrounding region. The results can therefore not be considered as representative of the whole of Late Iron Age and Roman Silchester. However, the pattern is considered to be genuine as the majority of samples from Iron Age settlements located closest to Silchester, on the edge of the Hampshire Downs around modern day Basingstoke (Brighton Hill South; Marnel Park), plot in the area of "calcareous" taxa on axis 1 and 2 (Fig. 3). The dissimilarity between the weed flora from these sites and from Silchester means it is unlikely that Silchester was receiving cereals cultivated at these settlements. The single Early Roman sample from 
Winchester Northgate House is plotted towards the positive end of axis 2, amongst samples from sites on the Hampshire Downs (Fig. 3). This suggests that crops were sourced for this Roman town from the local calcareous region, but more samples are needed to evaluate this pattern.

\subsection{Presence of archaeophytes}

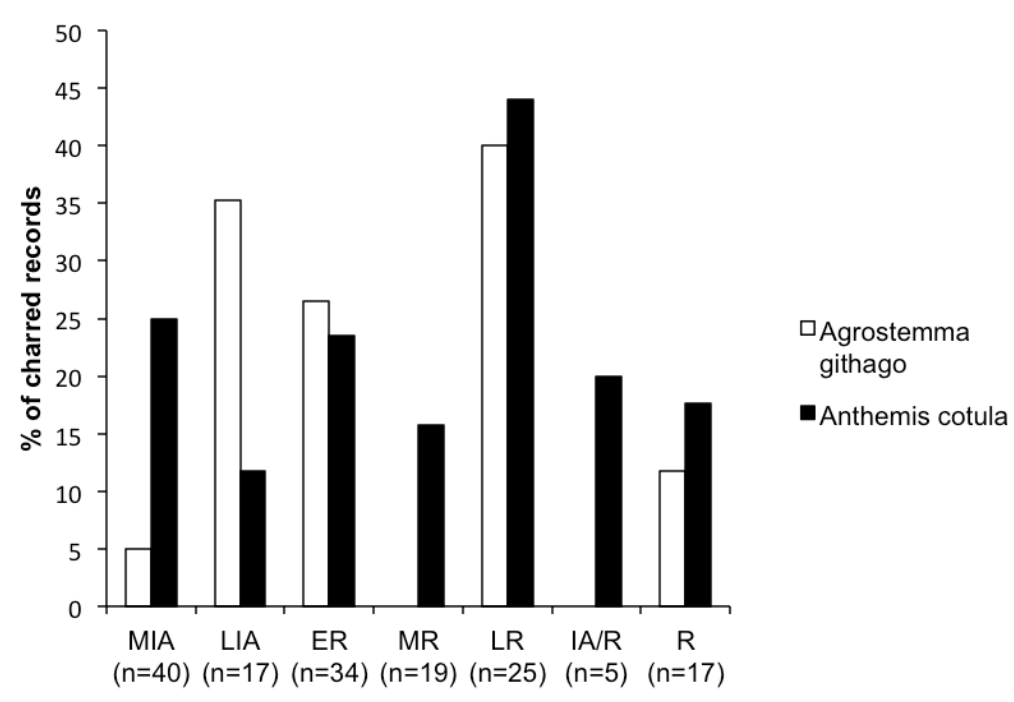

Fig. 7 Frequency of Agrostemma githago and Anthemis cotula from all sites in the regional study area with charred plant remains. Number in brackets refers to the number of sites per period.

A key limitation to this method is that two of the taxa located towards the negative end of axis 1 are considered to be archaeophytes, non-native taxa introduced prior to AD 1500 (Preston et al. 2004). Agrostemma githago and Anthemis cotula are usually classified at Roman or $1^{\text {st }}$ millennium BC introductions (Preston et al. 2004; Robinson 1981: 275). Their presence/absence in a sample may be indicative of the absence of this taxa from the local seed bank, rather than an avoidance of clay soils. However, an assessment of the presence of these taxa at sites in the regional study area (ESM Table 1) shows that a substantial number of identifications have been made from deposits dated by ceramics to the Middle and Late Iron Age. Fig. 7 shows that $A$. githago was present from the Middle Iron Age in this region, recorded at $5 \%$ of Middle Iron Age sites and increases to $40 \%$ of Late Roman sites, yet there is no major increase in any period. Similarly, Anthemis cotula was present at $25 \%$ of Middle Iron Age sites, $12 \%$ of Late Iron Age sites, increasing to $44 \%$ of Late Roman sites (Fig. 7 ). Again, whilst there is a general increase in frequency over time, there is no marked Roman introduction. If a low occurrence of these taxa is used as an argument for the lack of recognition of the cultivation of clay soils in the Iron Age, then the same can be said for the Roman period. It is important here to state that Agrostemma githago seeds would usually be present in a higher proportion in the 
fine-sieve product, and hence would be under-represented in the analysis of fine-sieving byproducts presented in this paper.

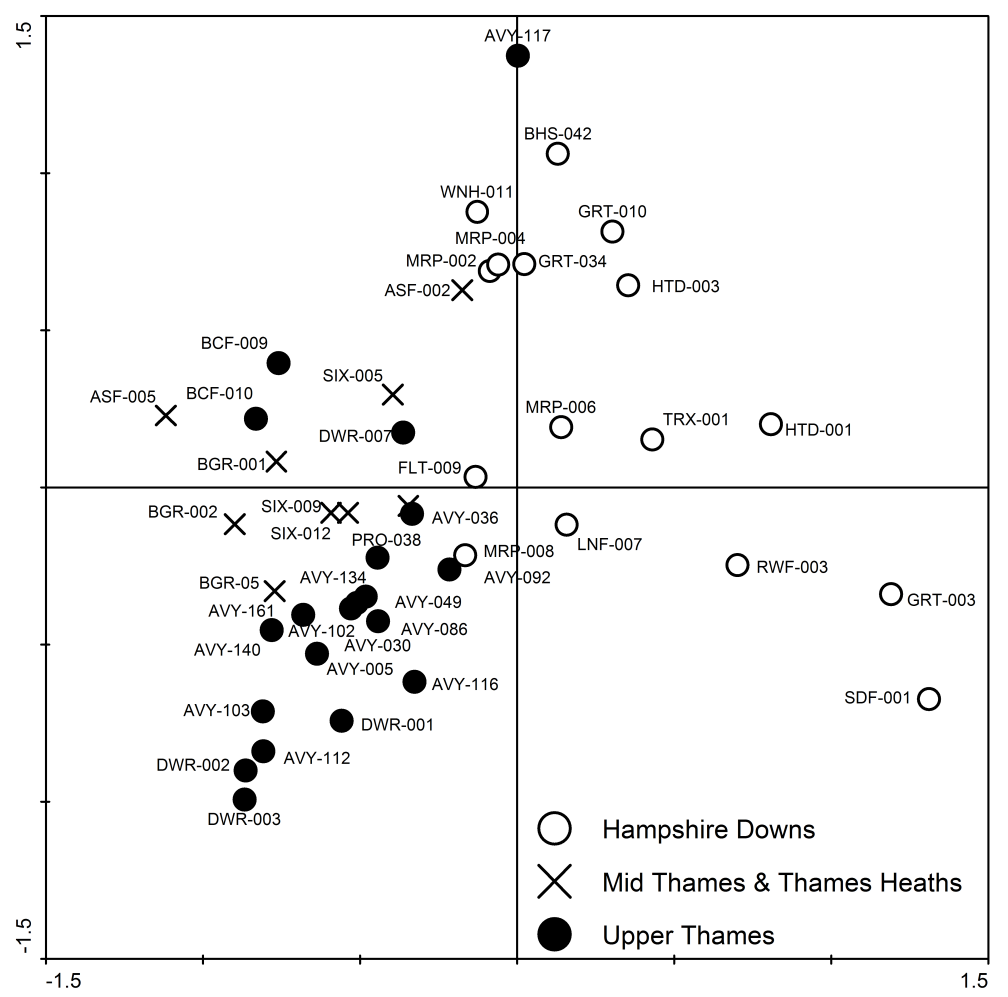

Fig. 8 Correspondence analysis plot of arable weeds from regional spelt FSBP samples, without Anthemis cotula and Agrostemma githago, samples classified by NCA.

1st (horizontal) and 2nd (vertical) axis. 45 samples, 48 taxa.

Some of these Iron Age records of archaeophyte could, of course, be intrusive Roman material (cf. Pelling et al. 2015). All sites with Mid Iron Age records of Anthemis cotula also have archaeobotanical evidence from Late Iron Age and Roman periods, other than Easton Lane and Lains Farm (ESM Table 1). Furthermore, all Iron Age records of $A$. cotula are present as 7 or fewer seeds per sample, with over half as single identifications, and all but one record of $A$. githago is of 5 or fewer seeds per sample. However, the presence of numerous pre-Roman finds makes it likely that there is a genuine Iron Age introduction of $A$. cotula and $A$. githago. The increased application of radiocarbon dating to Iron Age settlements (Hamilton et al. 2015), especially archived archaeobotanical remains, would enable this finding to be evaluated in the future. Returning to the correspondence analysis plot of arable weeds from fine-sieving byproducts, the removal of $A$. cotula and $A$. githago shows that the distribution of samples by their geographical region is very similar before (Fig. 3 ) and after (Fig. 8), as is the distribution of taxa (Fig. 9). The samples located towards the positive end of axis 1 and 2 are the same as before the removal of $A$. cotula and $A$. githago. The only difference is that samples plotted towards the negative end of axis 1, from sites in the Mid Thames, Thames Basin Heaths, and Upper Thames, are now less distinct from other samples on the negative end of axis 1. 


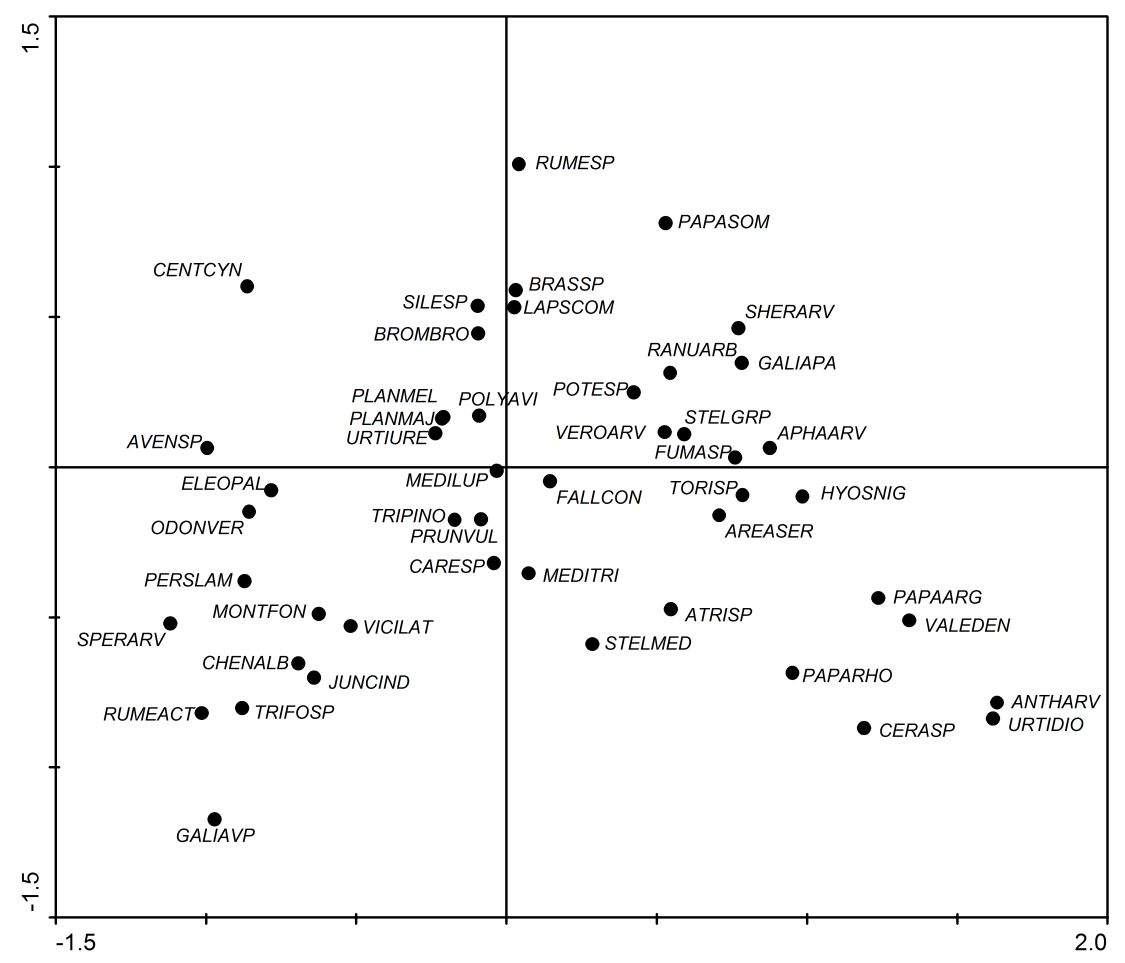

Fig. 9 Correspondence analysis plot of arable weeds from sample classified as spelt finesieve by-products, taxa plot. $1^{\text {st }}$ (horizontal) and $2^{\text {nd }}$ (vertical) axis. 45 samples, 48 taxa.

\section{Discussion}

\subsection{Archaeobotanical context}

This analysis has indicated that the range of arable weeds present alongside charred spelt glume bases recovered from Insula IX, Silchester, are distinct from those found at settlements on the calcareous soils of the Hampshire Downs, albeit based on a small number of samples. Hence, it is unlikely that Late Iron Age and Early Roman Silchester was reliant on farming settlements on the Hampshire Downs for the supply of cereals as suggested (Cunliffe 2012: 19; Sharples 2010: 173). The lack of evidence for cereal import to Silchester agrees with other aspects of the archaeobotanical record from Late Iron Age Insula IX, showing that agricultural activities were taking place on-site (Lodwick 2017), and new flavourings and fruits were being imported rather than staple foods (Lodwick 2014). This evidence also fits with the recent characterisation of oppida as examples of low-density urban sites, which were agriculturally self-sufficient (Moore 2017). In terms of the development of Silchester, this evidence suggests that the nucleation of local farming communities may have played a role in the development of this oppidum. This fits the internal model of oppida development, whereby new communities moved into new areas of the landscape and continued to cultivate the same crops (Hill 2007). The subsequent agricultural developments of hay meadow management and animal stabling, as evidenced at Silchester, can be understood as a reaction to this settlement nucleation (Lodwick 2017). 
Archaeobotanical evidence from the region does indicate later large-scale cereal movement. From the Mid Roman period, high density deposits of charred, and often germinated, cereal grains, spelt glume bases and coleoptiles have been recovered from corndriers, indicating the parching of cereals in advance of dehusking or their preparation for malt (Van der Veen 1989). Corndriers are present near Silchester at settlements at the edge of the Hampshire Downs at modern day Basingstoke (Coles et al., 2011; Wright et al., 2009), further west in the area around Danebury (Cunliffe and Poole, 2008) and also at the southern foot of the Berkshire Downs around Newbury (Birbeck 2000). It is likely that cereals were being processed in bulk before being transported to towns, and beyond.

\subsection{Archaeological context}

There is also much archaeological evidence indicating the large-scale storage and movement of crops across the landscape in the wider Iron Age and Roman period. In the Iron Age, storage pits and four-post structures indicate the large-scale storage of cereal crops. Yet whilst these have previously been held as evidence for cereal redistribution systems at Danebury (Jones, M. 1984), it now appears more likely that the cereals were being consumed at feasting events within the hillfort itself (Van der Veen and Jones 2006). Evidence of Late Iron Age cereal trade is largely based on the literary evidence of Strabo (Geography 4.5.2), whereby cereals, cattle and slaves were suggested as exports to the Roman world in exchange for glassware, ceramics and amphorae-born goods (Haselgrove 1982).

Shipwrecks, literary sources and the presence of granaries shows that cereals were being mobilised on a large-scale in the Roman world (Bowman and Wilson 2013; Erdkamp 2012). Whilst most towns and cities would have been sustained with cereals from their immediate hinterland, written sources describe how cereal grain was sourced from Egypt, Africa and Sicily for Rome (Aldrete and Mattingly 1999). In Rome, and many other towns and cities, large-scale wharves and warehouses evidence the transportation and storage of high volumes of cereals (Aldrete and Mattingly 1999). Written records related to Roman Britain are restricted to the export of cereal grain to the mid fourth century $A D$ Roman military on the Rhine frontier (Mattingly 2006: 505). This range of evidence makes it vital that the analysis of the weed composition of fine-sieving by-products as undertaken in this paper is widened in scope, to identify the scale of cereal exchange through the Iron Age and Roman periods. In order for this technique to be applied more widely, sampling strategies must be designed to ensure sufficiently large samples are taken from across feature types to produce assemblages of charred crops and weeds of sufficient size and character. 


\subsection{Archaeobotanical and isotopic evidence for crop movement}

Whilst this study has not provided any archaeobotanical evidence for regional crop movements, there are Roman sites where the presence of weed taxa far beyond their normal distribution indicate cereal trade. At Coney Street, York, a large deposit of charred spelt wheat from a warehouse just outside of the Colonia contained a number of archaeophytes; Delphinium spp., Consolida spp. and Lathyrus aphaca, indicating a continental origin (Williams 1979). A deposit of charred cereal grain at Caerleon contained seeds of Lathyrus aphaca, Lathyrus nissolia, Lathyrus cicera and Lens culinaris (Helbaek 1964), implying a southern European or Mediterranean origin. In London, the trading hub for Roman Britain in the first century AD, a large deposit of charred spelt wheat was recovered from a building located at the Roman Forum, burnt down in AD60/61. A Mediterranean or Near Eastern origin was suggested due to the presence of Triticum monococcum (einkorn) grains and the weed seeds A. githago, Lens culinaris, Vicia ervilia (Davis 2004; Straker 1987). However, there are also numerous examples of large grain deposits where the weed seeds are entirely consistent with a local source, such as at Verulamium (Fryer 2006), and South Shields granary (Van der Veen 1994), and others where too few weed seeds were present to draw any conclusions on the origin of the grain.

Beyond Britain, archaeobotanical evidence has also demonstrated the long distance movement of cereals in this period. A late second century AD shipwreck, found near to the fort of Laurium on the Lower Rhine, contained 14,650 clean Triticum dicoccum (emmer) wheat grains. These were transported loose in the boat's hull and were infested with various grain pests (Pals and Hakbijl 1992). Early first century $A D$ charred cereals from Arras, northern France were considered to be imported due to the presence of Agrostemma githago, Centaurea cyanus and Lithospermum arvense, all rare occurrences in the Iron Age region (Derreumaux and Lepetz 2008: 61).

The type of weed seeds present can only provide indirect evidence of the provenance of cereal crops. Recent developments in isotope analysis have begun to identify areas of crop origin based on direct analysis of cereal grains. The only study available for Britain analysed the ratios of $\delta 13 \mathrm{C}$ and $\delta 15 \mathrm{~N}$ of charred cereal grains of hulled barley and spelt wheat from two pits in Danebury hillfort. The ranges of $\delta 13 \mathrm{C}$ were $4.0 \%$ in both spelt wheat and barley, and of $\delta 15 \mathrm{~N}$ $5.2 \%$ and $4.1 \%$ for wheat and barley. This was beyond the variations recorded within both single plants and harvests, leading to the conclusion that the cereals had been harvested from a wide range of ecological zones (Lightfoot and Stevens 2012). Elsewhere, the results of carbon isotope analysis have suggested areas of the landscape from which crops may have been sourced, based on the $\delta 13 \mathrm{C}$ values of charred cereal grains and experimental values for water availability (Wallace et al. 2015). The use of strontium isotope ratios to source plant foods is at a preliminary stage (Fiorentino et al. 2014: 220). Experimental work at Çatalhöyük has analysed strontium isotope ratios $\left({ }^{87} \mathrm{Sr} /{ }^{86} \mathrm{Sr}\right)$ from modern plant samples. Higher values were recorded 
from the alluvial plain samples compared to the limestone terrace samples (Bogaard et al. 2014). Further modern studies in Iraqi Kurdistan have shown that ${ }^{87} \mathrm{Sr} /{ }^{86} \mathrm{Sr}$ isotope ratios vary in modern plant remains sourced from the alluvium flood plain and limestone foothills, albeit based on small sample sizes (Elliot et al. 2015).

\section{Conclusion}

This paper presents a quantitative regional analysis of arable weed seeds from selected cropprocessing by-products in Iron Age-Roman Britain. This analysis has shown that the geological region has a strong influence on the range of arable weed seeds present alongside charred cereals. No evidence for crop-movement between geological regions was detected, indicating that the Late Iron Age oppidum at Silchester was unlikely to have been reliant on the calcareous Hampshire Downs for cereals. Rather, this suggests the oppida may have been agriculturally self-sufficient, and that nucleation of local farming communities played a role in the development of the oppidum. Establishing mechanisms of food supply to the town in the Roman period requires much more extensive analysis of samples from these phases and surrounding settlements in order to further evaluate the pattern identified in this paper.

It is considered that the comparative analysis of arable weeds across geologically distinctive regions is a useful tool for identifying the regional source of cereal crops. Given the archaeological evidence for Late Iron Age and Roman crop movements, this technique should be used in combination with the analysis of regional variations in the density of charred cereals, and crop isotope analysis. The low occurrence of samples representing unmixed free-threshing cereal (barley and free-threshing wheat) products and by-products in the study region means that the method will be largely restricted to the glume wheats; spelt wheat and, if present in dominant quantities, emmer wheat. In the future, the adjustment of sampling strategies to produce assemblages with large numbers of samples, containing high number of items, in combination with the standardisation of archaeobotanical weed taxa between specialists, would provide a more robust dataset for such analyses.

\section{References}

Aldrete GS, Mattingly DJ (1999) Feeding the city: the organization, operation, and scale of the supply system for Rome. In: Potter D, Mattingly D (eds) Life, death, and entertainment in the Roman Empire. The University of Michigan Press, Ann Arbor, pp 171-204

Bendrey R, Hayes TE, Palmer MR (2009) Patterns of Iron Age horse supply: an analysis of strontium isotope ratios in teeth. Archaeometry 51(1):140-150.

Birbeck V (2000) Archaeological investigations on the A34 Newbury Bypass, Berkshire/Hampshire, 1991-7: Technical reports. Wessex Archaeology, Salisbury, pp 47-50 
Bogaard A (2004) Neolithic farming in central Europe: an archaeobotanical study of crop husbandry practices. Routledge, London

Bogaard A (2011) Plant use and crop husbandry in an early Neolithic village: Vaihingen an der Enz, Baden-Württemberg. Habelt, Bonn

Bogaard A, Henton E, Evans J, Twiss K, Charles M, Vaiglova P, Russell N (2014) Locating land use at Neolithic Çatalhöyük, Turkey: the implications of $87 \mathrm{Sr} / 86 \mathrm{Sr}$ signatures in plants and sheep tooth sequences. Archaeometry 56(5): 860-877. doi:10.1111/arcm.12049

Bogaard A, Hodgson J, Nitsch E, Jones G, Styring A, Diffey C, Pouncett J, Herbig C, Charles $M$, Ertuğ F, Tugay O, Filipovic D, Fraser R (2015) Combining functional weed ecology and crop stable isotope ratios to identify cultivation intensity: a comparison of cereal production regimes in Haute Provence, France and Asturias, Spain. Veg. Hist. Archaeobotany 25(1): 5773

Bogaard A, Jones G, Charles M, Hodgson J (2001) On the archaeobotanical inference of crop sowing time using the FIBS method. J. Archaeol. Sci 28(11): 1171-1183

Booth P, Dodd A, Robinson M, Smith A (2007) The Thames through time: the archaeology of the gravel terraces of the upper and middle Thames: the early historical period, AD 1-1000.

Oxford University School of Archaeology, Oxford

Bowman A, Wilson A (2013) Introduction: quantifying Roman agriculture. In: Bowman A, Wilson A (eds) The Roman agricultural economy: organization, investment, and production. Oxford University Press, Oxford, pp 1-32

Branch N, Green C (2004) The environmental history of Surrey. In: Cotton J, Crocker G, Graham A (eds) Aspects of archaeology \& history in Surrey: towards a research framework for the county. Surrey Archaeological Society, Guildford, pp 1-18

Brewis A, Bowman P, Rose F (1996) The flora of Hampshire. Harley Books, Colchester

Campbell G (2000a) Plant utilization: the evidence from charred plant remains. In: Cunliffe B The Danebury Environs programme. The prehistory of a Wessex landscape. Institute of Archaeology, Oxford, pp 45-59

Campbell G (2000b) The charred plant remains. In: Cunliffe B, Poole C The Danebury Environs programme: the prehistory of a Wessex landscape. Suddern Farm, Middle Wallop, Hants, 1991 and 1996, Volume 2, Part 3. Institute of Archaeology, Oxford, pp 193-198 
Campbell G (2008a) Charred plant remains. In: Cunliffe B, The Danebury Environs Roman programme: a Wessex landscape during the Roman era Volume 2 pt. 3. Fullerton, Hants, 2000 and 2001. English Heritage and Oxford University School of Archaeology, Oxford, pp 161-164

Campbell G (2008b) Plant remains. In: Cunliffe B The Danebury Environs Roman programme: a Wessex landscape during the Roman era Volume 2 pt. 2. Grateley South, Grateley, Hants, 1998 and 1999. English Heritage and Oxford University School of Archaeology, Oxford, pp 166-174

Campbell G (2008c) Charred and mineralized plant remains. In: Cunliffe B The Danebury Environs Roman programme: a Wessex landscape during the Roman era Volume 2 pt. 1. Houghton Down, Longstock, Hants, 1997. English Heritage and Oxford University School of Archaeology, Oxford, pp 146-159

Campbell G (2008d) Plant remains. In: Cunliffe B The Danebury Environs Roman programme: a Wessex landscape during the Roman Era Volume 2 pt. 5. Rowbury Farm, Wherwell, Hants, 2003. English Heritage and Oxford University School of Archaeology, Oxford, pp 146-154

Carruthers W (1991) The carbonised and mineralised plant remains. In: Bellamy P Investigations of the Prehistoric Landscape Along the Route of the A303. Proc. Hamps. Field Club \& Archaeol. Society 47: 36-41

Carruthers W (1995) Plant remains. In: Fasham P, Keevil G, Coe D, Newman R Brighton Hill South (Hatch Warren): an Iron Age farmstead and deserted medieval village in Hampshire. Trust for Wessex Archaeology, Salisbury, pp 56-60

Carruthers W (2010) Charred and waterlogged plant remains. In: Framework Archaeology, Landscape evolution in the Middle Thames Valley: Heathrow Terminal 5 excavations volume 2. CD Rom. Framework Archaeology, Oxford and Salisbury

Carruthers W (2011) Charred and mineralised plant remains. In: Ford B, Teague S, Biddulph E. Winchester - a city in the making: archaeological excavations between 2002 and 2007 on the sites of Northgate House, Staple Gardens and the former Winchester Library, Jewry St. Oxford Archaeology, Oxford

Charles M (1998) Fodder from dung: the recognition and interpretation of dung-derived plant material from archaeological sites. Enviro Archaeol 1:111-122

Coles S, Lowe J, Ford S (2011) Excavation of a Roman enclosure at Park Prewett Hospital, Basingstoke, Hampshire. Proc. Hamps. Field Club \& Archaeol. Society 66:39-74 
Crawley M (2005) The flora of Berkshire. Brambley Books, Harpenden

Creighton J (2000) Coins and power in Late Iron Age Britain. Cambridge University Press, Cambridge

Cunliffe B (1984) Danebury: an Iron Age hillfort in Hampshire. Volume 1: the excavations 1969-1978: the site. CBA Research Report No 52a, vol. 1. CBA, London

Cunliffe B, Poole C (2008) The Danebury Environs Roman programme. A Wessex Landscape during the Roman era Volume 1 - Overview. English Heritage and Oxford University School of Archaeology, Oxford

Cunliffe B (2012) Calleva in context. In: Fulford M (ed) Silchester and the study of RomanoBritish urbanism. Journal of Roman Archaeology Supplementary Series Number 90, Portsmouth, Rhode Island, pp 15-21

Cunliffe B, Poole C (2000) The Danebury Environs programme: the prehistory of a Wessex landscape. Volume 1 - introduction. English Heritage and Oxford University School of Archaeology, Oxford

Davis A (2004) The plant remains. In: Dunwoodie L Pre-Boudican and later activity on the site of the Forum. Museum of London Archaeology Service Archaeology Studies Series 13, London, pp 54-57

Davis O (2013) Re-interpreting the Danebury assemblage: houses, households, and community. Proc. Prehistoric Soc. 79, 353-375

Derreumaux M, Lepetz S (2008) Food supply at two successive military settlements in Arras (France): an archaeobotanical and archaeozoological approach. In Stallibrass S, Thomas R (eds) Feeding the Roman army: the archaeology of production and supply in NW Europe. Oxbow Books, Oxford, pp 52-68

Ede J (2000) Charred plant remains from Bagnor Road. In: Birbeck V (ed) Archaeological investigations on the A34 Newbury Bypass, Berkshire/Hampshire, 1991-7: Technical reports. Wessex Archaeology, Salisbury, pp 47-50

Elliot S, Bendrey R, Whitlam J, Rauf Aziz K, Evans J (2015) Preliminary ethnoarchaeological research on modern animal husbandry in Bestansur, Iraqi Kurdistan: Integrating animal, plant and environmental data. Environ. Archaeol. 20(3):283-303

Erdkamp P (2008) Grain market intervention in the Roman world. In: Alston R, van Nijf OM (eds), Feeding the ancient Greek city. Peeters, Leuven, pp 109-125 
Erdkamp P (2012) A forum on trade - the grain trade in the Roman world. In: Scheidl W (ed.) The Cambridge companion to the Roman economy. Cambridge University Press, Cambridge, pp 304-308

Fairbairn A, Austin P (2001) Archaeobotanical evidence. In: Barber A, Holbrook, N A Romano-British settlement to the rear of Denchworth road, Wantage, Oxfordshire: evaluation and excavation in 1996 and 1998. Oxoniensia 66:325-333

Fiorentino G, Ferrio JP, Bogaard A, Araus JL, Riehl S (2014) Stable isotopes in archaeobotanical research. Veg. Hist. Archaeobotany 24(1):215-227

Firbank L (1988) Agrostemma Githago L. (Lychnis Githago (L.) Scop.). J. Ecology 76(4): $1232-1246$

Fryer V (2006) Charred cereals and other remains. In: Niblett R Verulamium: excavations within the Roman Town 1986-88. Britannia 37, 53-188

Fulford M (2000) The organisation of legionary supply: the Claudian invasion of Britain. In: Brewer R (ed.) Roman fortresses and their legions. Society of Antiquaries, London, pp 41-50

Fulford M, Timby J (2000) Late Iron Age and Roman Silchester: excavations on the site of the Forum Basilica, 1977, 1980-86. Britannia Monograph Series No. 15, Society for the Promotion of Roman Studies, London

Hall A (2003) Recognition and characterisation of turves in archaeological occupation deposits by means of macrofossil plant remains. Centre for Archaeology Report 16/2003

Hamilton WD, Haselgrove C, Gosden C (2015) The impact of Bayesian chronologies in the British Iron Age. World Archaeol. 47(4):642-660

Haselgrove C (1982) Wealth, prestige and power: the dynamics of Late Iron Age political centralization in south-east England. In: Renfrew A, Shennan S (eds) Ranking, resource and exchange. Cambridge University Press, Cambridge, pp 79-88

Helbaek H (1964) The Isca grain, a Roman plant introduction in Britain. New Phytologist 63(2):158-164

Hill JD (2007) The dynamics of social change in Later Iron Age eastern and south-eastern England c. 300 BC-AD 43. In: Haselgrove C, Moore T (eds) The Later Iron Age in Britain and beyond. Oxbow Books, Oxford, pp 16-40 
Hill JD (2011) How did British middle and late pre-Roman Iron Age societies work (if they did)? In: Moore T, Armada X (eds) Atlantic Europe in the first millennium BC: crossing the divide. Oxford University Press, Oxford, pp 242-263

Hill MO, Preston CD, Roy DB (2004) PLANTATT. Attributes of British and Irish plants: status, size, life history, geography and habitats. Centre for Ecology \& Hydrology, Huntingdon Jones G (1984) Interpretation of archaeological plant remains: ethnographic models from Greece. In: Casparie W, Van Zeist W (eds) Plants and ancient man: studies in palaeoethnobotany. A.A. Balkema, Rotterdam, pp 43-61

Jones G (1991) Numerical analysis in archaeobotany. In: van Zeist W, Wasylikowa K, Behre KE (eds) Progress in Old World Palaeoethnobotany. A.A. Balkema, Rotterdam, pp 63-80 Jones G, Bogaard A, Halstead P, Charles M, Smith H (1999) Identifying the intensity of crop husbandry practices on the basis of weed floras. Annual of the Br. Sch. Athens 94:167-189

Jones G, Charles M, Bogaard A, Hodgson J (2010) Crops and weeds: the role of functional weed ecology in the identification of crop husbandry methods. J. Arch. Sci. 37:70-77

Jones M (1981) The development of crop husbandry. In: Jones M, Dimbleby, G (eds) The environment of man: the Iron Age to the Anglo-Saxon period. British Archaeological Reports (British Series) 87, Oxford, pp 95-127

Jones M (1984) The plant remains. In: Cunliffe B (ed.) Danebury: an Iron Age hillfort in Hampshire volume 2: the excavations, 1969-1978: the finds. Council for British Archaeology Research Report 52, London, pp 483-495

Jones M (1985) Archaeobotany beyond subsistence reconstruction. In: Barker G, Gamble C (eds) Beyond domestication in prehistoric Europe. Academic Press, London, pp 107-128

Jones M (2007) A feast of Beltain? Reflections on the rich Danebury harvests. In: Gosden C, Hamerow $\mathrm{H}$, de Jersey $\mathrm{P}$, Lock $\mathrm{P}$ (eds) Communities and connections: essays in honour of Barry Cunliffe. Oxford University Press, Oxford, pp 142-153

Jones M, Robinson M (1984) The crop plants. In: Miles D (ed.), Archaeology at Barton Court Farm, Abingdon, Oxon. Oxford Archaeological Unit and Council for British Archaeology, Oxford, pp 9:E10-9:F8

Kay Q, (1971a) Anthemis cotula L. J. Ecology 59(2):623-636

Kay Q (1971b) Anthemis arvensis L. J. Ecology 59(2):637-648 
Kottek M, Grieser J, Beck C, Rudolf B, Rubel F (2006) World map of the Köppen-Geiger climate classification updated. Meteorl. Z. 15:259-263

Lightfoot E, Stevens RE (2012) Stable isotope investigations of charred barley (Hordeum vulgare) and wheat (Triticum spelta) grains from Danebury Hillfort: implications for palaeodietary reconstructions. J. Archaeol. Sci. 39(3):656-662. doi: 10.1016/j.jas.2011.10.026

Lodwick L (2014) Condiments before Claudius: new plant foods at the Late Iron Age oppidum at Silchester, UK. Veg. Hist. Archaeobotany 23(5):543-549

Lodwick LA (2015) An archaeobotanical analysis of Silchester and the wider region.

Unpublished DPhil thesis, University of Oxford

Lodwick LA (2017) Agricultural innovations at a Late Iron Age oppidum: archaeobotanical evidence for flax, food and fodder from Calleva Atrebatum, UK. Quatern. Int. 460: 198-219. doi:10.1016/j.quaint.2016.02.058

Madgwick R, Mulville J (2015) Feasting on fore-limbs: conspicuous consumption and identity in later prehistoric Britain. Antiquity 89:629-644

Madgwick R, Lewis J, Grimes V, Guest P (2017) On the hoof: exploring the supply of animals to the Roman legionary fortress at Caerleon using strontium $\left({ }^{87} \mathrm{Sr} /{ }^{86} \mathrm{Sr}\right)$ isotope analysis. Archaeol Anthropol Sci. doi:10.1007/s12520-017-0539-9

Mathers S, Smith N (2000) Geology of the Reading district - a brief explanation of the geological map. Sheet explanation of the British geological survey. 1:50,000 Sheet 268 Reading (England \& Wales). British geological society Keyworth, Nottingham

Mattingly D (2006) An imperial possession: Britain in the Roman empire, 54 BC - AD 409. Penguin Books, London

McKenna R (2012) Carbonized and waterlogged plant macrofossils and charcoal. In: Preston S. (ed.) Settlement and landscape archaeology in the middle Thames valley: Slough and environs. Thames Valley Archaeological Service Monograph 14, Reading, pp 161-172

Met Office (2015) Website accessed 28/06/2015

http://www.metoffice.gov.uk/public/weather/climate/

Minniti C, Valenzuela-Lamas S, Evans J, Albarella U (2014) Widening the market. Strontium isotope analysis on cattle teeth from Owslebury (Hampshire, UK) highlights changes in livestock supply between the Iron Age and the Roman period. J. Archaeol. Sci. 42:305-314 DOI: 10.1016/j.jas.2013.10.008

Moore T (2007) Perceiving communities: exchange, landscapes and social networks in the later Iron Age of western Britain. Oxf. J. Archaeol. 26(1):79-102 
Moore T (2012) Beyond the oppida: polyfocal complexes and late Iron Age societies in southern Britain. Oxf. J. Archaeol 31(4):391-417

Moore T (2017) Beyond Iron Age 'towns' examining Oppida as examples of low-density urbanism. Oxf. J. Archaeol 36(3):287-304 DOI: 10.1111/ojoa.12116

Natural England (2014) National Character Areas - defining England's natural boundaries.

Retrieved May 14, 2014, from http://www.naturalengland.org.uk/publications/nca/default.aspx

New JK (1961) Spergula arvensis L. J. Ecology 49(1):205-215

Pals JP, Hakbijl T (1992) Weed and insect infestation of a grain cargo in a ship at the Roman fort of Laurium in Woerden (Province of Zuid-Holland). Rev. Palaeobotany and Palynology 73:287-300

Pelling R (2009) Charred plant remains. In: Wright J (ed.) Excavation of prehistoric and Romano-British sites at Marnel Park and Merton Rise (Popley) Basingstoke, 2004-8. Wessex Archaeology, Salisbury, pp 54-65

Pelling R, Campbell G, Carruthers W, Hunter K, Marshall P (2015) Exploring contamination (intrusion and residuality) in the archaeobotanical record: case studies from central and southern England. Veg. Hist. Archaeobotany 24(1):85-99.

Pitt M (2010) Re-thinking the southern British oppida: networks, kingdoms and material culture. Eur. J. Archaeol. 13(1):32-63

Preston C, Pearman D, Hall A (2004) Archaeophytes in Britain. Botanical J. Linn. Soc.145, 257-294

Robinson M (1981) The Iron Age to early Saxon environment of the upper Thames terraces. In: Jones M, Dimbleby G (eds) The environment of man: the Iron Age to the Anglo-Saxon period. BAR British Series 87. Archaeopress, Oxford, pp 251-277

Robinson M (1992) Environmental archaeology of the river gravels: past achievements and future directions. In: Fulford M, Nichols E (eds) Developing landscapes of lowland Britain. Society of Antiquaries, London, pp 47-62

Roskams S (1999) The hinterlands of Roman York: present patterns and future strategies. In: Hurst $\mathrm{H}$ (ed) The Coloniae of Roman Britain: new studies and a review. Journal of Roman Archaeology Supplementary Series 36, Portsmouth, Rhode Island, pp 45-72

Sauer E (2002) The Roman invasion of Britain (AD 43) in imperial perspective: a response to Frere and Fulford. Oxf. J. Archaeol. 21(4):333-363 
Sharples N (2010) Social relations in later prehistory: Wessex in the first millennium BC.

Oxford University Press, Oxford

Stace C (2010) New flora of the British Isles (2nd edition). Cambridge University Press, Cambridge

Stevens C (1996) Iron Age and Roman agriculture in the upper Thames valley: archaeobotanical and social perspectives. Unpublished DPhil thesis, University of Cambridge Stevens C (2003) An investigation of agricultural consumption and production models for prehistoric and Roman Britain. Environ. Archaeol. 8:61-76

Strabo (translated by Jones HJ 1949) Geography. William Heinmann Ltd, London

Straker V (1987) Carbonized cereal grain from first-century London: a summary of the evidence for importation and crop processing. In: Marsden P (ed.) The Roman Forum site in London. H.M.S.O., London, pp 151-155

Summers J, Campbell G, (2008) Charred plant remains. In: Cunliffe B (ed.) The Danebury Environs Roman programme: a Wessex landscape during the Roman era Volume 2 pt. 4. Thruxton, Hants, 2002. English Heritage and Oxford University School of Archaeology, Oxford, pp 102-105

Ter Braak CJF, Ŝmilauer P (2002) CANOCO reference manual and CanoDraw for Windows User's Guide. Biometris, Wageningen

Van der Veen M (1989) Charred grain assemblages from Roman-period corn driers in Britain. Archaeol. J. 146, 302-19

Van der Veen M (1992) Crop husbandry regimes: an archaeobotanical study of farming in Northern England 1000 BC - AD 500. J.R. Collis Publications, Sheffield

Van der Veen M (1994) Reports on the biological remains. In: Bidwell P and Speak S Excavations at South Shields Roman Fort. Society of Antiquaries of Newcastle upon Tyne Monograph Series 4, Newcastle upon Tyne, pp 243-269

Van der Veen M (2014) Arable farming, horticulture, and food: expansion, innovation, and diversity in Roman Britain. In: Millett M, Revell L, Moore A (eds) The Oxford Handbook of Roman Britain. Oxford University Press, Oxford DOI:

10.1093/oxfordhb/9780199697713.013.046.

Van der Veen M, Fieller N (1982) Sampling seeds. J. Archaeol. Sci. 9(3):287-298 
Van der Veen M, Jones G (2006) A re-analysis of agricultural production and consumption: implications for understanding the British Iron Age. Veg. Hist. Archaeobotany 15(3):217-228 Van der Veen M, Livarda A, Hill A (2007) The archaeobotany of Roman Britain: current state and identification of research priorities. Britannia 38:181-210

Van der Veen M, O'Connor TP (1998) The expansion of agricultural production in Late Iron Age and Roman Britain. In: Bayley J (ed) Science in archaeology: an agenda for the future. English Heritage Occasional Paper, London, pp 127-143

Wallace MP, Jones G, Charles M, Fraser R, Heaton THE, Bogaard A (2015) Stable carbon isotope evidence for Neolithic and Bronze Age crop water management in the Eastern Mediterranean and Southwest Asia. PLoS ONE 10(6). doi: e0127085.

doi:10.1371/journal.pone.0127085

Weiss E, Kislev M (2004) Plant remains as indicators of economic activity: a case study from Iron Age Ashkelon. J. Archaeol. Sci. 31:1-13

Williams D (1979) The plant remains. In: Kenward HK, Williams D (eds) Biological evidence from the Roman warehouses in Coney Street. Council for British Archaeology, York, pp 52-62

Wright J, Powell A, Barclay A (2009) Excavation of prehistoric and Romano-British sites at Marnel Park and Merton Rise (Popley) Basingstoke, 2004-8. Wessex Archaeology, Salisbury

ESM Table 1: Regional sites with archaeobotanical data.

ESM Table 2: Standardisation of cereals and arable taxa.

ESM Table 3: Sample crop-processing calculations and meta-data.

ESM Figures 1 and 2: Supplementary correspondence analysis plots. 